\title{
Sancassania chelone Oudemans, 1916 (Acari: Acaridae) Associated with Pest Beetles: New Records and New Hosts in Hungary
}

\author{
J. KONTSCHÁN*, V. KEREZSI, B. KISS and M. TÓTH \\ Plant Protection Institute, Centre for Agricultural Research, Hungarian Academy of Sciences, \\ H-1525 Budapest, P.O. Box 102, Hungary
}

(Received: 5 June 2016; accepted: 15 June 2016)

\begin{abstract}
The hypopi of the species Sancassania chelone Oudemans, 1916 were collected from four pest beetle species, namely Melolontha melolontha (Linnaeus, 1758); Melolontha hippocastani Fabricius, 1801; Holochelus aequinoctialis (Herbst, 1790) and Tropinota hirta Poda, 1761. The infestation rate was the highest in H. aequinoctialis (80\%), while it was $50 \%, 28 \%$ and $13 \%$ in M. hippocastani, M. melolontha and T. hirta, respectively. The majority of the mites were found on wings in case of the two Melolontha species, in contrary, the mites were present on the abdomen of the H. aequinoctialis and T. hirta. Melolontha hippocastani Fabricius, 1801; Holochelus aequinoctialis (Herbst, 1790) and Tropinota hirta (Poda, 1761) are new host species of S. chelone.
\end{abstract}

Keywords: Sancassania chelone, pest beetles, new host, Hungary.

Some species from the beetle family Scarabaeidae are important agricultural pests in Hungary (Sipos et al., 2012; Varga and Molnár, 2013) causing damages on roots and leaves of cultivated plants in agricultural and horticultural areas. The association of mites with scarabaeid beetles is a scarcely investigated field of the acarology in Hungary. Till today only one paper mentioned mites from the scarabaeid pest beetles, Kontschán (2015) presented two mesostigmatan mites from the family Laelapidae in association with Anoxia orientalis Krynicky, 1832 and Polyphylla fullo Linnaeus, 1758. In this year we studied the mites of four different scarabaeid pest species [Melolontha melolontha (Linnaeus, 1758); Melolontha hippocastani Fabricius, 1801; Holochelus aequinoctialis (Herbst, 1790) and Tropinota hirta Poda, 1761]. These pest beetles are very common in Hungary in spring and in early summer, but we have very few information about the pest beetle associated mites from our region, the Carpathian Basin. Some years ago (Mašán, 1998), a new mesostigmatan mite species was discovered in Slovakia; the new species [Hypoaspis (Hypoaspis) rizotrogi Mašán, 1998] was collected on the body of H. aequinoctialis. During our new studies, we found large number of the hypopi of Sancassania chelone Oudemans, 1916.

\footnotetext{
* Corresponding author; e-mail: kontschan.jeno@agrar.mta.hu
} 
Sancassania chelone was collected firstly by Erőss and Mahunka (1971) in different dung samples from Hungary. In this paper, Erőss and Mahunka (1971) did not mention the stages of the collected mites, but we suppose that these specimens were adults, because the hypopi of Sancassania chelone Oudemans, 1916 is not a typical dung-dwelling mite, usually it occurs in association with different species of the scarabaeid beetles (Coleoptera, Scarabaeidae) (Klimov, 1997). In the present paper we investigate the rate of the infestation of these beetle species and the position preferences of this mite on the beetles' body.

\section{Materials and Methods}

The beetle species were collected in three different parts of Hungary. Specimens of species Melolontha melolontha (Linnaeus, 1758) and Melolontha hippocastani Fabricius, 1801 were caught on a solitary willow tree in a garden of Pilisvörösvár $(15 \mathrm{~km}$ to the north of Budapest) using the singling method. The specimens of Holochelus aequinoctialis (Herbst, 1790) were collected after the emergence from the soil in Budapest, district XIX, using the singling method. The Tropinota hirta (Poda, 1761) were collected by CSALOMON ${ }^{\circledR}$ VARb3k funnel traps baited with a floral attractant (Schmera et al., 2004; Tóth et al., 2004). The bodies of the beetles were studied under microscope. The number of mites on different parts of beetle body (wings, thorax and abdomen) was determined separately. After this, the mites were moved from beetle bodies into lactic acid on microscope slides.

\section{Results}

Short description of hypopus of Sancassania chelone Oudemans, 1916 (Fig. 1)

Diagnosis: Small, pale mite. Dorsal body slightly convex. Anterior body tapering anteriorly into a small cone with rounded apex. Dorsal side of body divided into two shields, by sejugal furrow. Sejugal furrow well developed, covered by membranous cuticle. Propodosomal shield bearing three pairs of needle-like setae, but vi longer than sci and sce, hysterosomal shield ten pairs of needle-like setae, h1 Epimera I fused to Y, epimera II free, epimera III and IV weakly sclerotised and free. Suctorial shield large, palposoma with two pairs of short and one pair of larger setae. Setae $\omega 1$ spatuliform.

Distribution: This species is widely distributed in the Palearctic region, from Europe to Japan (Klimov and Tolstikov, 2011).

Ecology: The adult mites can be found in organic material rich soils and dung, while the hypopi live on body of scarabaeid beetles. Because the adult mites prefer the dung and soil, we need to suppose that the hypopi are using the beetle only for transport and they are not parasites of them. We can also presume that the beetles can be infested by the hypopi before leaving the soil. 


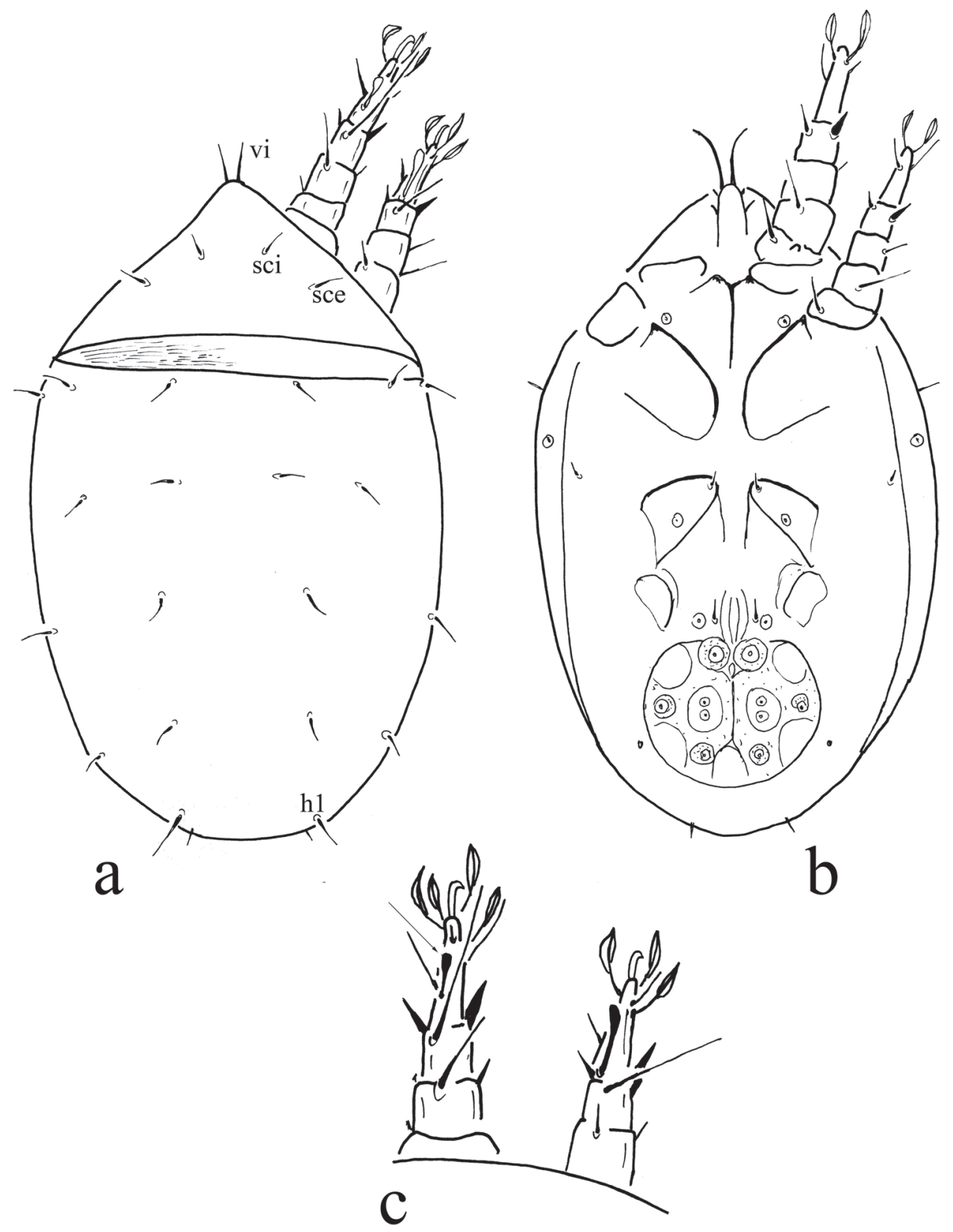

Fig. 1. Sancassania chelone Oudemans, 1916, hypopus: a: dorsal view of body, b: ventral view of body, c: dorsal view of end of leg I and II (arrow shows seta $\omega 1$ ) 
Notes to the taxonomy: Fain (1977) mentioned three synonymous names of the S. chelone following Samšinak (1960) paper, Tyroglyphus mycophygus Moniez, 1892; Caloglyphus moniezi Zachvatkin, 1937 and Caloglyphus spinitarsus Nesbitt, 1945. The hypopi of S. chelone are very similar to S. michaeli (Oudemans, 1924), but several differences can be found in the case of adults (see Stammer, 1957).

\section{Rate and place of the infestation}

We collected only five specimens of $H$. aequinoctialis in the sampling place, out of which four specimens were infested by the mite hypopi, so the infestation rate was $80 \%$. Two beetle specimens had mites on their wings ( 8 and 1 specimens). The beetle bodies were covered in higher number by the mites; all infested $H$. aequinoctialis carried mites on the abdomens. The highest mite number on abdomen was 159 , the lowest was 8 , and average was 48.

More than the half (55\%) of the investigated M. hippocastani specimens were infested with $S$. chelone hypopi, $90 \%$ of the infested beetle specimens had mites on their wings and $54 \%$ had mites on the abdomen. The average numbers of the mite specimens were 7 and 3 on the wings and on the abdomen, respectively. Within the investigated beetle species we found mites on the thorax only in the case of $M$. hippocastani.

The infestation rate was lower in the specimens of $M$. melolontha, only $28 \%$ of the studied specimens carried mites on their wings and abdomen. The average mite number was similar to the previous species, six on the wings and three on the abdomen.

In T. hirta, only three specimens of the investigated 22 had S. chelone on their body; the infestation rate is $13 \%$, which is the lowest within the studied pest beetles. We did not find mites on the wings and only few numbers (2-1-2) of the hypopi were detected on the beetle abdomen. The reason of the absence of the mites on wings of $T$. hirta can be the different type of elytra of this beetle. The two elytra are fused on their central part and the beetle cannot elevate them during the flight therefore the wings are mostly hidden. On the contrary, the elytra are not fused in the other three investigated species, during the flight the elytra are elevated, the wings are free and the hypopi can colonize them more easily.

\section{Discussion}

The phoresy is an important phenomenon for mites to be transported from one point to another. The majority of the mite taxa use this possibility to search new and source rich habitat. The phoresy is absolutely different from the parasitism, because the passengers do not feed on the host (Walter and Proctor, 2013). The hypopi (deutonymphs) of the family Acaridae usually use the insects for transportation between two habitats, therefore these mites are very often collected on the bodies of different insects, like beetles. Moreover, numerous new species are discovered and described from insect body as well, mostly from hymenopterans and from beetles (like Moser and Roton, 1971; Fain et al., 1999; Philips, 2009). The phoretic species from the genus Sancassania are very rarely found on beetle pests, only Al-Deeb and Enan (2010) mentioned the first record of this genus from 
United Arab Emirates collected on beetle Oryctes agamemnon Burmeister 1847, which is one of the most important pest beetles of date palm in Middle-East. Our results show, that further investigations are needed to reveal the significance of these beetles in transportation of mites belonging to different acarine taxa.

\section{Acknowledgement}

This research was supported by OTKA 108663.

\section{Literature}

Al-Deeb, M. and Enan, M. (2010): First record of a phoretic Astigmatid mite Sancassania sp. (Acaridae: Astigmata) on Oryctes agamemnon Burmeister (Coleoptera: Scarabaeidae) in UAE. Int. J. Agri. Biol. 12, 157-160.

Erőss, J. and Mahunka, S. (1971): Investigations on coprophilous and stercoricolous macrochelids (Acari, Gamasina) in Hungary, as possible agents in the control of synanthropous flies. Parasitol. Hung. 4, 215-226.

Fain, A. (1977): Caractéres compares des hypopes de Rhizoglyphus echinopus Fum. et Robin et de Sancassania chelone Oudemans (Astigmates: Acaridae). Acarologia 29, 105-111.

Fain, A., Engel, M. S., Flechtmann, C. and OConnor, B. (1999): A new genus and species of Acaridae (Acari) phoretic on Thectochlora alaris (Hymenoptera: Halictidae: Augochlorini) from South America. Int. J. Acar. 25, 163-172.

Klimov, P. B. (1997): New data on the fauna and biology of acarid mites (Acari, Acaridae) from the Far East. Acarina 5, 69-72.

Klimov, P. B. and Tolstikov, A. V. (2011): Acaroid mites of Northern and Eastern Asia (Acari: Acaroidea). Acarina 19, 252-264.

Kontschán, J. (2015): Ismeretek a hazai kártevő rovarok atkáiról I.: Két faunára új atkafaj (Acari: Mesostigmata: Laelapidae) cserebogarakról (Coleoptera: Melolonthinae). [Contribution to the mites of Hungarian pest insects I.: First record of two melolontinae (Coleoptera) associated mites (Acari: Mesostigmata: Laelapidae).] Növényvédelem 51, 417-420. (in Hung.)

Mašán, P. (1998): Two new mesostigmatic mites (Acarina; Proctolaelaps, Hypoaspis) associated with erotylid and melolonthine beetles (Coleoptera: Erotylidae, Scarabaeidae) from Slovakia. Entomol. Problems 29, 19-22.

Moser, J. C. and Roton, L. M. (1971): Mites associated with Soutern pine bark beetles in Allen Parish, Louisiana. Can. Entomol. 103, 1775-1798.

Philips, J. R. (2009): The mite (Acarina) fauna of trogid beetles (Coleoptera: Trogidae). Int. J. Acar. 35, 1-17.

Samšinak, K. (1960): Über einige myrmekophile milben aus der familie Acaridae. Acta Soc. Entom. Cechosl. 57, 185-192.

Schmera, D., Tóth, M., Subchev, M., Sredkov, I., Szarukán, I., Jermy, T. and Szentesi, Á. (2004): Importance of visual and chemical cues in the development of an attractant trap for Epicometis (Tropinota) hirta Poda (Coleoptera: Scarabaeidae). Crop Prot. 23, 939-944.

Sipos, K., Fejes-Tóth, A., Pásztor, B., Vétek, G., Pénzes, B., Míg, J. and Tóth, M. (2012): Nyáron rajzó cserebogarak csapdázása. [Trapping of the summer swarming melolonthid beetles.] Agrofórum 23, 50-52. (in Hung.)

Stammer, H. J. (1957): Beiträge zur systematik und ökologie mitteleuropäischer Acarina. Band I. Tyroglyphidae und Tarsonemini Teil 1. Akademische Verlagsgesellschaft Geest and Poortig K.-G. Leipzig, pp. 1-384.

Tóth, M., Schmera, D. and Imrei, Z. (2004): Optimization of a chemical attractant for Epicometis (Tropinota) hirta Poda. Z. Naturforsch. 59, 288-292. 
Varga, Sz. and Molnár, M. (2013): A májusi és az erdei cserebogár, valamint az ellenük való védekezési lehetőségek. [The maybeetle and the forest cockchafer in Hungary, and possibilities for protection against the species.) Erdészettudományi Közlemények 3, 215-227. (in Hung.)

Walter, D. E. and Proctor, H. (2013): Mites: Ecology, Evolution and Behaviour. Life at a Microscale. Second ed. Springer, Heidelberg, pp. 1-494. 